\title{
KERANKGA KERJA MANAJEMEN HUBUNGAN MASYARAKAT DALAM MENCIPTAKAN MADRASAH UNGGUL
}

\author{
Subairi \\ Pascasarjana Universitas Nurul Jadid \\ E-mail: subairinf@gmail.com
}

\begin{abstract}
Abstrak
Kemajuan suatu madrasah atau lembaga pendidikan perlu ditunjang bersama-bersama oleh seluruh elemen, lingkungan kecil (keluarga), pihak madrasah (lembaga pendidikan), maupun lingkungan (masyarakat). Tiga elemen ini haruslah berpadu, bersinergi, dengan harapan membuahkan hasil atau kualitas outcome pendidikan yang baik/mapan. Harapan ini tentunya harus dijalankan/ditingkatkan oleh pihak penyelenggara pendidikan (madrasah). dalam artian madrasah berperan aktif dalam menjalin komunikasi dengan elemen lingkungan (masyarakat), baik dengan pengajar, tenaga pendidikan,wali siswa, ataupun dengan masayarakat sekitar. dalam mewujudkan hubungan yang baik ini, dalam pelaksanaannya diperlukan adanya pengelolaan hubungan masyarakat. Madrasah dalam era sekarang sangatlah memerlukan peran aktif dari masyarakat dalam menunjang keberhasilannya, baik dalam mendidik, memberikan peluang besar dan melahirkan putra bangsa yang cakap, mandiri. agar kelak, anak didik bisa beradaptasi dengan lingkungan, dalam menjalin komunikasi yang baik. Pengelolaan manajemen hubungan masyarakat sangatlah penting dilakukan, agar jalinan komunikasi antara lembaga pendidikan dan lingkungan sekitar (masyarakat) pada umunya saling mendorong dan berpartisipasi dalam menunjang keberhasilan suatu lembaga pendidikan.
\end{abstract}

Kata kunci : Kerangka Manajemen Humas, Madrasah Unggul.

\begin{abstract}
The progress of a madrasa or educational institution needs to be supported jointly by all elements, small environment (family), madrasas (educational institutions), and the environment (community). These three elements must be combined, synergized, with the hope of producing results or good quality education outcomes. This expectation must of course be carried out / improved by the education provider (madrasa). in the sense that madrasas play an active role in establishing communication with elements of the environment (community), both with teachers, education personnel, student guardians, or with surrounding communities. in realizing this good relationship, the implementation of community relations management is needed. Madrasas in the current era really require an active role from the community in supporting its success, both in educating, providing great opportunities and giving birth to capable, independent sons of the nation. so that later, students can adapt to the environment, in establishing good communication. Management of public relations management is very important, so that communication links between educational institutions and the surrounding environment (community) generally encourage and participate in supporting the success of an educational institution.
\end{abstract}

Keywords : Public Relations Management Framework, Creating Superior Madrasas

\section{Pendahuluan}

Dalam menentukan kemajuan dan kemunduran kualitas pendidikan maka diperlukan adanya ilmu pengetahuan yang dikuasai dan dipahami. 


\section{2 | Subairi}

Dalam hal ini tidaklah lepas dari sebuah usaha besar lembaga dalam mengikuti perkembangan dunia pendidikan saat ini. ${ }^{1}$ Pada dasarnya Madrasah tidak akan bisa berkualitas atau bermutu baik bahkan unggul tanpa adanya manajemen yang baik dalam peningkatan mutu pendidikan. dalam menjaga dan meningkatkan kualitas diperlukan adanya manajemen hubungan masayarakat. Peranan penting ini haruslah dijalankan oleh pimpinan madrasah bersama dengan masyarakat khususnya stakholder pada umumnya untuk melakukan peningkatan taraf pendidikan, bahkan perubahan status guna menjadikan madarsah lebih maju dan unggul. ${ }^{2}$

Apabila ada suatu madrasah yang lebih baik dari madrasah yang lainnya maka perlu adanya penelusuran lebih dalam lagi bagaimana lembaga madrasah tersebut menjalankan manajemen atau berupaya maksimal dalam meningkatkan mutu guna memproses sebuah kurikulum dengan usahausaha yang lebih mapan dan baik. ${ }^{3}$ Pelayanan dan menjalin komunikasi kepada lingkungan (masyarakat) semakin hari semakin dituntut untuk memberikan yang terbaik dan profesional. Disebabkan adanya kebutuhan dan keinginan masyarakat yang tinggi akan pendidikan untuk melanjutkan studi yang lebih baik lagi dalam lembaga pendidikan. Saat ini kejelian dan kedetail-an masyarakat dalam memilih lembaga pendidikan. Karena masyarakat sebagai konsumen atau pengguna jasa pendidikan. Kini lembaga harus berupaya maksimal untuk menitikberatkan kepada kebutuhan masyarakat sebagai pelanggan tetapnya. madrasah dituntut dan berusaha untuk melibatkan masyarakat untuk merumuskan kemajuan lembaga pendidikan. ${ }^{4}$

Menurut mulyasa Konsep pelayanan manajemen madrasah harus ditetapkan agar lembaga pendidikan bisa mengelola sumber daya yang ada sesuai dengan kepentingan lembaga pendidikan tersebut. Pada saat ini lembaga pendidikan berlomba-lomba dalam memikat perhatian, minat masyarakat. Tugas penting ini sangat dibutuhkan oleh dunia pendidikan adanya hubungan masayarakat (public relation) dalam lembaga pendidikan. dalam Hal ini bukan hanya berlaku bagi lembaga pendidikan negeri saja akan tetapi bagi lembaga swasta. Terbentuknya reputasi yang baik dalam lembaga pendidikan ini dibutuhkan pengelola humas agar tercipta komunikasi, promosi serta penilaian masyarakat yang baik kepada lembaga pendidikan tersebut. ${ }^{5}$ Guna mempertahankan dan membangun citra positif lembaga/madrasah terhadap lingkungan (masyarakat) agar tercermin reputasi madrasah yang baik. Bisa dilihat pada saat ini banyak lembaga swasta yang mempromosikan keunggulan masing-masing madrasahnya

\footnotetext{
${ }^{1}$ Hasan Baharun, 'Manajemen Kinerja Dalam Meningkatkan Competitive Advantage Pada Lembaga Pen Didikan Islam', Jurnal Ilmu Tarbiyah “At - Tajdid, 5.2 (2016), 244.

2 Rosi Rosita, 'Usaha Kepala Sekolah Dalam Meningkatkan Mutu Pendidikan Islam (Studi Kasus Di MTS AL-INAYAH Bandung)', Jurnal Tarbawy, 3.1 (2016), 75-89.

3 Nurul, 'Strategi Manajemen Humas Dalam Menyampaikan Program Unggulan Madrasah', Al Tanzim, 2.1 (2018), 46.

4 M. Maskur, 'Eksistensi Dan Esensi Pendidikan Madrasah Di Indonesia', Jurnal Pendidikan Dan Pembelajaran Dasar Volume, 4.1 (2017), 101-19.

5 Nur Izza Afkarina, 'Strategi Komunikasi Humas Dalam Membentuk Public Opinion Lembaga Pendidikan', Jurnal Idaarah, 2.1 (2018), 61.
} 
kepada khalayak umum (masyarakat) untuk menarik konsumen sebanyakbanyaknya.

Pimpinan madrasah diharapkan mampu membina hubungan baik dengan masyarakat secara terus menerus, dan mendapatkan dukungannya. Oleh karena itu program-program madrasah dan masalah yang dihadapi oleh lembaga tersebut disampaikan kepada masyarakat. Agar lingkungan (masyarakat) bisa memahami, mengerti dan memberikan masukan positif guna menunjang perkembangan madrasah. Tujuan dari penyampaian ini taklepas dari terciptanya simpati dan umpan balik dan mengundang partisipasi aktif masyarakat dalam pengembangan program madrasah lebih lanjut. Dari itu peran aktif hubungan masayarakat dalam lembaga pendidikan sangat penting untuk mengembangkan dan memelihara kerjasama antara pihak lingkungan madrasah (intern) dan lingkungan sekitar (masyarakat)/(ekstern) tentunya. ${ }^{6}$

\section{Metode}

Pada kajian ini, penelitian yang digunakan adalah penelitian kualitatif dengan menggunakan pendekatan studi perpustakaan (library research). Kajian pustaka atau studi pustaka merupakan kegiatan yang mengembangkan aspek teoritis maupun aspek manfaat praktis. ${ }^{7}$ Kajian pustaka berfungsi untuk membangun konsep atau teori yang menjadi dasar studi dalam penelitian. ${ }^{8}$ Adapun beberapa sumber yang digunakan antara lain; buku-buku teks, jurnal ilmiah, refrensi statistik, hasil-hasil penelitian dalam bentuk skripsi, tesis, desertasi, dan internet, serta sumber-sumber lainnya yang relevan. ${ }^{9}$ Kajian pustaka yang dilakukan untuk menemukan kerangka kerja manajemen hubungan masyarakat dalam kaitannya dengan teciptanya madrasah yang unggul

\section{Manajemen Hubungan Masyarakat}

Berbicara manajemen humas tak lepas dari pengertian manajemen itu sendiri. Salah satunya sebagai berikut: Manajemen sebagai suatu proses kerja melalui orang lain untuk mencapai tujuan organisasi dalam lingkungan yang berubah. Proses ini berpusat pada penggunaan yang efektif dan efisien terhadap penggunaan sumberdaya manusia. ${ }^{10}$ Pendapat tersebut jelas bahwa manajemen sangat berperan penting terutama manajemen humas, karena

\footnotetext{
${ }^{6}$ Ersin Idrangingrum, 'Peran Kepala Sekolah Dan Partisipasi Dari Masyarakat Dalam Implementasi Manajemen Berbasis Sekolah Unruk Mewujudkan Kualitas Pendidikan Madrasah Tsanawiyah Negeri Kota Madiun', Jurnal Studi Sosial, 3.1 (2018), 11-21.

7 Sukardi. Metodologi Penelitian Pendidikan Kompetensi dan Praktiknya. (Jakarta : Bumi Aksara, 2013), h.33 2014), h.5

8 V.Wiratna Sujarweni. Metodologi Penelitian. (Yogyakarta : Pustaka Baru Perss,

${ }_{9}^{9}$ Anwar Sanusi. Metodologi Penelitian Bisnis. (Jakarta : Salemba Empat, 2016), h.32

${ }^{10}$ Jazuli Mukhtar and Ichwan Nugroho, 'Pondok Pesantren ( Studi Kasus Di Pondok Pesantren As ' Adiyah Belawa Baru, Masamba , Sulawesi Selatan )', Al-Tanzim, 03.01 (2019), 82-101.
} 


\section{4 | Subairi}

suatulembaga pendidikan tidak akan berkembang dengan baik tanpa adanya hubungan yang baik dengan mayarakat. Kenyataan ini menuntut pengelola madrasah untuk bersikap rasional dan berorientasi kepada masyarakat luas. Karena pada hakikatnya masyarakat mengharapkan suatu lembaga pendidikan yang berkualitas dan menjanjikan masa depan yang cerah. ${ }^{11}$

Manajemen adalah suatu proses perencanaan, pengorganisasian, kepemimpinan, dan pengendalian upaya dari anggota organisasi serta penggunaan semua sumber daya yang ada pada organisasi untuk mencapai tujuan organisasi yang telah ditetapkan. ${ }^{12}$ Ada pula yang mengertikan manajemen itu keseluruhan aktivitas yang berkenaan dengan melaksanakan pekerjaan organisasi melalui fungsi-fungsi perencanaan, pengorganisasian, pengarahan, dan pengawasan untuk mencapai tujuan organisasi yang telah ditentukan dengan bantuan sumber daya organisasi (manusia, uang, bahan, mesin, dan metode) secara efisien dan efektif. ${ }^{13}$ Beberapa makna tentang manejemen di atas dapat disimpulkan bahwa serangkaian kegiatan di mana ada proses yang berbeda, yaitu perencanaan, pengorganisasian, penggerakkan dan pengendalian sehingga dapat memanfaatkan sumber daya yang ada untuk mencapai tujuan secara efektif dan efisien. ${ }^{14}$

Terkait dengan definisi hubungan masyarakat sangat beragam dalam pengertiaanya Diantarannya sebagai berikut :Manajemen hubungan masyarakat adalah salah satu cara yang harus ada di lembaga pendidikan, beberapa di antaranya terbukti hari ini bahwa banyak lembaga pendidikan dapat berkembang pesat karena manajemennya yang sangat baik dan terarah. Meningkatkan partisipasi masyarakat bukanlah pekerjaan yang mudah karena dalam upaya ini diperlukan rencana terpadu dan komprehensif. Terkait dengan fungsi pendidikan sebagai upaya mempertahankan, mempelajari dan meningkatkan komunitas sosial budaya. ${ }^{15}$ Hubungan Masyarakat adalah profesi dan ilmiah, yang terkait dengan upaya untuk membangun hubungan yang harmonis antara organisasi dan komunitasnya, sehingga menghasilkan saling pengertian antara keduanya, menciptakan citra positif organisasi, menumbuhkan kepercayaan publik dan meningkatkan prestasi. Dalam menjalankan profesinya, Hubungan Masyarakat dituntut untuk dapat menyampaikan pesan-pesan positif tentang organisasi kepada masayarakat melalui berbagai strategi dan

11 Syamsuddin, 'Penerapan Fungsi-Fungsi Manajemen Dalam Meningkatkan Mutu Pendidikan', Jurnal Idaarah, I.1 (2017), 3-4.

12 Hasan Baharun, 'Manajemen Kinerja Dalam Meningkatkan Competitive Advantage Pada Lembaga Pendidikan Islam', At-Tajdid: Jurnal Ilmu Tarbiyah, 5.2 (2016), 243-62.

13 Ma'ruf Abdullah, Manajemen Dan Evaluasi Kinerja Karyawan, ed. by Budi Rahmat Hakim (Yogyakarta: Aswaja Pressindo, 2014).

14 Sugiono, 'Strategic Planning: Shaping or Emerging From Organisations', AlTanzim : Jurnal Manajemen Pendidikan Islam, 2.2 (2018), 177-84.

15 Vitri Yuniarti, 'Aplikasi Manajemen Humas Dalam Meningkatkan Partisipasi Masyarakat Di MAN Malang 1', Jurnal Manajemen Pendidikan, 1.1 (2017), 5. 
teknik, sehingga apa yang disampaikan dapat diterima dan dipahami sesuai harapan yang diharapkan organisasi tersebut. 16

Frank jeffkins, mengartikan humas adalah :"public relations pratice is the planned and sustained effort to establish and maintain goodwill and undersatanding between an organization an its public" Pelaksanaan rancangan kegiatan yang berkesinambungan. arah dari rancangan tersebut untuk membangun dan saling menjaga pengertian antara organisasi dan publiknya. ${ }^{17}$ Dalam artian bahwa hubungan masyarakat yaitu membina jalinan dengan baik antar seseorang dengan yang lain dalam memahami, mengembangkan dan berpartisipasi untuk memajukan. Hubungan masyarakat adalah kegiatan untuk menanamkan dan memperoleh pengertian, dukungan, kepercayaan, serta penghargaan pada dan dari publik suatu badan pada khususnya dan masyarakat pada umumnya. Hubungan masyarakat pada dasarnya bertujuan menciptakan dan mengembangkan persepsi citra positif madrasah di masyarakat. Pentingnya pendidikan menjadikan kerjasama madrasah dengan masyarakat sebagai kebutuhan dasar. Kerjasama tersebut dimaksudkan demi kelancaran pendidikan di madrasah pada umumnya dan untuk meningkatkan prestasi belajar siswa pada khususnya. ${ }^{18}$

Manajemen hubungan masyarakat ialah Sebuah kegiatan yg direncanakan dalam mendorong dan mempengaruhi masyarakat melalui implementasi tanggung jawab sosial berdasarkan komunikasi timbal balik untuk mendapatkan manfaat dari kedua belah pihak. Kegiatan tersebut bisa dilaksanakan oleh perorangan atau pergrup dalam arah perencaanan dan memelihara atupun mempertahankan suatu ide kerjasama yang efisien dalam menjelaskan tujuan dari kegiatan tersebut secara gamblang dan mudah dimengerti. ${ }^{19}$

Dari beberapa definisi diatas dapat disimpulkan bahwa manajemen hubungan masyarakat Suatu kegiatan yang direncanakan untuk mendorong dan mempengaruhi masyarakat melalui pelaksanaan tanggung jawab sosial berdasarkan komunikasi keduanya untuk mendapatkan kebermanfaatan dari keduanya, Kegiatan-kegiatan ini dapat dilakukan oleh individu atau kelompok dalam arah perencanaan dan pemeliharaan atau mempertahankan gagasan kerja sama yang efisien dalam menjelaskan tujuan kegiatan dengan cara yang jelas dan dapat dimengerti. sifat hubungan masyarakat dengan institusi yang berhubungan dengan kelompok (komunitas). Dengan kata lain, antara lembaga pendidikan dan pelaksana mereka, baik guru, staf pendidikan, pendidik, siswa. dan lingkungan di sekitarnya dapat berupa wali

16 Diah Wulandari Trimanah, 'Prinsip Public Relations Dalam Ajaran Islam Menurut Persepsi Anggota Perhumas Jawa Tengah', Asi, Vol 11 (1), Juni 2018, 11.1 (2018), 66-74.

17 Mohammad Hasan, 'Manajemen Public Relations dalam Membangun Citra dan Kontestasi Perguruan Tinggi Keagamaan Islam Swasta (Studi pada Sekolah Tinggi Agama Islam Syaikhona Moh. Kholil Bangkalan)', Nuansa, 14 (2017), 35.

18 Ira Nur Harini, 'Manajemen Hubungan Masyarakat Dalam Upaya Peningkatan Pencitraan Sekolah', Jurnal Inspirasi Manajemen Pendidikan, Vol. 4 No. 4, April 2014, Hlm. 8 20, 4.4 (2014), 8-20.

19 Dian Marhaeni K Mubarok, 'Konstruksi Prinsip Kinerja Public Relations Dalam Pandangan Syariat Islam', Jurnal Messenger, VIII.2 (2016), 20-34. 
siswa, komunitas, institusi lain, atau institusi lain. Dalam domain ini jelas bahwa PR adalah salah satu elemen penting dalam lembaga.

\section{Humas: Fungsi dan Tugasnya dalam Madrasah}

Fungsi hubungan masyarakat berarti berbicara masalah kegunaan humas dalam lembaga madrasah. Fungsi humas adalah penyampaian informasi dari dua kelompok penting, baik dari masyarakat dan lingkungan (komunitas, pemangku kepentingan) yang memberikan ide, hubungan dan dukungan untuk membuat kemajuan. ${ }^{20}$

Beberapa fungsi humas menurut pakar diantaranya Cutlip \& Centre and Can field berdasarkan ciri khas kegiatan humas sebagai berikut :

1. Mendukung kegiatan utama manajemen dalam mencapai tujuan bersama melalui fungsi-fungsi yang melekat dalam pengelolaan lembaga / organisasi

2. Membina hubungan yang harmonis antar organisasi dan publik yang menjadi target audiens.

3. Identifikasi segala sesuatu yang terkait dengan pendapat, persepsi, dan tanggapan masyarakat terhadap lembaga yang mereka wakili atau sebaliknya.

4. Melayani keinginan publik dan menyumbang saran kepada pimpinan manajemen untuk tujuan dan manfaat bersama.

5. Menciptakan komunikasi dua arah timbal balik dan berbagi informasi, publikasi, dan pesan dari lembaga / organisasi ke publik atau sebaliknya untuk mencapai citra positif bagi kedua belah pihak. ${ }^{21}$

Menurut Edward L. Bernays ada tiga fungsi utama humas, yaitu:

1. Pemberi informasi kepada masyarakat

Memberikan informasi kepada masyarakat maksudnya petugas humas memberikan informasi di dalam organisasi tersebut kepada khalayak masyarakat sehingga mereka dapat mengetahui dan memahami suasana yang ada dalam organisasi tersebut

2. Melakukan rayuan untuk mengubah sikap dan perbuatan secara langsung

Melakukan rayuan untuk mengubah sikap dan perbuatan secara langsung, yaitu Isu yang ada dalam organisasi dan berkembang di masayarakat dapat di pengaruhi dan diarahkan oleh humas kepada halhal yang positif.

3. Berusaha untuk memadukan sikap dan tindakan dari suatu organisasi sesuai dengan sikap dan tindakan masyarakat atau sebaliknya, maksudnya pelaksana humas harus mampu menyelaraskan sikap yang dilaksanakan oleh organisasi kepada masyarakat ataupun sebaliknya, dan mewujudkan tindakan yang diinginkan oleh masyarakat kepada

20 Yanuar Luqman, 'Peran Dan Posisi Hubungan Masyarakat Sebagai Fungsi Manajemen Perguruan Tinggi Negeri Di Semarang', Interaksi: Jurnal Ilmu Komunikasi, 2.1 (2013) <https://ejournal.undip.ac.id/index.php/interaksi/article/view/5397/4836>.

21 Pandit Isbianti, 'Peran Humas Sebagai Upaya Menjalin Kerja Sama', Jurnal Manajemen Pendidikan, 01.01 (2009), 41-49. 
organisasi tersebut. harapannya Hubungan yang harmonis antara organisasi dengan masyarakat agar dapat dicapai. ${ }^{22}$

Mengutip dari Zulkarnain Nasution dalam bukunya Manajemen Humas di Lembaga Pendidikan, terkait fungsi humas pada lembaga pendidikan tak beda jauh dengan fungsi humas di madrasah diantaranya sebagai berikut:

1. Mampu sebagai mediator dalam berkomunikasi langsung (komunikasi tatap muka) dan tidak langsung (melalui media / pers) kepada pimpinan lembaga publik (dosen / guru, karyawan dan mahasiswa / siswa).

2. Berkontribusi dan membantu aktifitas yang berkaitan dengan pengumuman lembaga pendidikan. Dalam hal ini hubungan masyarakat bertindak sebagai manajer informasi kepada komunitas intern dan eksternal, seperti: menyampaikan informasi kepada pers dan publisitas

3. Memberikan anggapan/citra positif kepada lembaga madrasahnya. ${ }^{23}$

Dari penjelasan di atas, dapat disimpulkan bahwa fungsi humas di madrasah adalah Menjalin komunikasi yang baik antara pihak madarasah dengan pihak masyarakat dalam (intern) baik guru, karyawan, dan siswa maupun dengan pihak luar (ekstern) wali murid, masyarakat sekitar madrasah dan pihak terkait (stakeholder) dalam rangka menunjang kegiatan madrasah dalam mencapai tujuan organisasi, dan mencegah terjadinya krisis kepercayaan, baik yang di timbulkan dari pihak pelaksana madrasah maupun dari masyarakat sekitar, menumbuhkan kesadaran berpendidikan, saling memberi informasi baik dari dalam maupun dari luar agar terpenuhi peningkatan dalam pemeliharaan madarasah membangun tanggapan positif dari luar kepada madrasah.

Ruang lingkup hubungan masyarakat disebuah madrasah dalam lembaga pendidikan ialah :

1. Menjalin hubungan ke dalam (Public Internal)

Membina da menjalin Hubungan kedalam yang dimaksud adalah komunikasi dari pihak yang menjadi bagian dari unit, badan, organisasi lembaga pendidikan. Misalnya: Seorang kepala humas harus mampu mengidentifikasi, mengenali hal-hal yang menimbulkan gambaran negatid dalam lembaga pendidikan, sebelum kebijakan dilaksanakan.

2. Menjalin hubungan ke luar (public eksternal)

Menjalin hubungan dengan masyarakat yang dimaksud ialah. Mengusahakan dan mengoptimalkan tumbuhnya sikap dan gambaran komunikasi yang positif terhadap lembaga yang diwakili. ${ }^{24}$

Dalam arti lain, tugas hubungan masyarakat di lembaga madrasah adalah menciptakan hubungan internal yang kondusif melalui pemeliharaan

22 Adi Nugroho Rahutomo, 'Strategi Humas Dalam Mempublikasikan Informasi Pelayanan Publik Pada Pt Pln (Persero) Rayon Di Samarinda Ilir', EJournal Ilmu Komunikasi, 1.2 (2013), 324-40.

23 Elfridawati Mai Dhuhani, 'Manajemen Humas Dalam Meningkatkan Mutu Madrasah Studi Kasus Di Madrasah Ibtidiyah Terpadu (Mit) As-Salam Ambon', Jurnal Al- $i$ l $t$ i z a $M, 1.1$ (2016), 40.

24 Asrul Anam, 'Strategi Hubungan Masyarakat Dalam Upaya Meningkatkan Mutu Pendidikan Di Mts Darut Taqwa', Jurnal Al-Murabbi, 1.1 (2016), 176. 
setiap ikatan kerja dan memelihara hubungan yang harmonis antara pemimpin, tenaga pendidik dan tenaga kependidikan, dan siswa. Selain itu, hubungan masyarakat di lembaga pendidikan madrasah juga mencakup hubungan eksternal, di mana hubungan masyarakat di madrasah harus membangun dan mempertahankan citra dan reputasi positif madrasah dan membina hubungan baik dengan media dan membangun hubungan yang harmonis dengan pelanggan (siswa dan masyarakat luas) ) sehingga madrasah dapat memperoleh kepercayaan publik.

\section{Kerangka Kerja Manajemen Hubungan Masyarakat dalam Menciptakan Madrasah Unggul}

Membangun hubungan di lembaga madrasah memainkan peran yang sangat penting dalam mencapai tujuan madrasah. dalam meningkatkan pencapaian tujuan-tujuan ini, perlu untuk menyampaikan informasi secara akurat dan jelas kepada masyarakat, baik hubungan di dalam lembaga madrasah maupun di luar lembaga yaitu masyarakat, guna dapat menimbulkan saling pengertian dan niat baik antara masyarakat dengan madrasah. W. Emerson Reck menjelaskan humas adalah kelanjutan dari proses penetapan keputusan, pemilihan pelayanan-pelayanan dan sikap yang disesuaikan dengan kepentingan orang - orang atau golongan agar orang atau lembaga yang mendapatkan kepercayaan dan niat baik dari mereka. Kedua, penerapan kebijaksanaan, layanan dan sikap adalah untuk memastikan pemahaman dan penghargaan terbaik. ${ }^{25}$ Niat baik dan kerjasama dapat tercipta karena ada komitmen yang dilakukan oleh humas lembaga madarasah untuk menanamkan saling kepercayaan dan pengertian kepada masyarakatnya. Kemudian diambil tindakan nyata lembaga untuk mencapai komitmen tersebut. ${ }^{26}$

Mengutip dari bukunya Suryosubroto "Humas dalam Dunia Pendidikan ada dua kegiatan hubungan masyarakat yang harus dilaksanakan oleh madrasah yakni: ${ }^{27}$

1. Kegiatan keluar (Eksternal)

Kegiatan ini saling berkorelasi yang ditujukan kepada masyarakat di luar warga madrasah. Ada dua hal yang bisa dilaksanakan, kegiatan ini bisa langsung (bertemu muka) dan tidak langsung. Kegiatan tatap muka, misalnya rapat bersama dengan pengurus Yayasan, diskusi dengan tokoh-tokoh masyarakat. Kegiatan eksternal tidak langsung adalah kegiatan yang berhubungan dengan masyarakat melalui media tertentu. Kegiatan eksternal yang melalui media misalnya: informasi melalui TV, penyebaran informasi melalui radio, penyebaran informasi melalui media cetak, pameran madrasah dan diterbitkannya sendiri diterbitkan majalah atau buletin madrasah dengan maksud ditunjukan kepada publik di luar madrasah.

\footnotetext{
${ }^{25}$ Mulyono, 'Teknik Manajemen Humas Dalam Pengembangan Lembaga Pendidikan Islam', Jurnal Ulumuna, XV.1 (2011), 168.

${ }^{26}$ Kriyanto, 'Teknik Praktis Riset Komunikasi: Disertai Contoh Praktis Riset Media, Public Relations, Advertising 21' (Yogyakarta: Media Akademi, 2006), p. 21.

27 Kriyanto.
} 


\section{Kegiatan Internal}

Kegiatan ini merupakan pemberian informasi kepada warga madrasah yang diminta, yaitu pendidik, tenaga kependidikan dari semua siswa. Aktivitas internal dapat dibedakan dengan aktivitas langsung (tatap muka) dan tidak langsung (melalui media tertentu).

Kegiatan yang bersifat langsung, misalnya: upacara madrasah, pertemuan majelis guru, rekreasi bersama, penjelasan lisan pada berbagai kesempatan. Sedangkan kegiatan tidak langsung, misalnya: penyampaian informasi melalui surat edaran, penggunaan papan buletin di madrasah, penyelenggaraan majalah dinding, penerbitan buletin madrasah untuk dibagikan kepada warga, iklan / pemberitahuan khusus melalui media massa pada kesempatan tertentu dan lainnya kegiatan tatap muka yang tidak rutin seperti seni pertunjukan, tutup tahun.

Ada beberapa tahapan dalam mendukung kerangka kerja manajemen hubungan masyarakat dalam menciptakan lembaga madarasah yang unggul, antara lain :

1. Planning (Perencanaan),

Tahap awal dalam proses Perencanaan berupa penerapan tujuan dan standar, menentukan aturan dan prosedur, serta membuat rencana dan prediksi akan apa yang akan terjadi.

a. Membina hubungan harmonis dengan masyarakat dalam lingkungan lembaga madarasah, seperti tenaga kerja, tenaga pendidik, dan peserta didik, dan menjalin hubungan dengan masyarakat luar di lingkungan lembaga madrasah, seperti orang tua peserta didik, masyarakat dan di luar lembaga lembaga pendidikan. ${ }^{28}$

b. Membina dan mempererat komunikasi dua arah baik ke lingkungan lembaga madrasah dan masyarakat luar dengan menyampaikan informasi dan mengumumkan hasil penelitian dan berbagai keputusankeputusan yang telah disetujui pimpinan. ${ }^{29}$

c. Menentukan dan mengkaji suatu pandangan atau berbagai diskusi baik yang ada dilembaga madrasah ataupun yang ada dimasyarakat sekitar.

d. Mampu mendengar keinginan atau aspirasi yang ditemukan di masyarakat. ${ }^{30}$

e. Berperilaku terampil, cekatan dalam mengartikan keputusan pimpinan dengan baik.

Perencanaan merupakan keharusan bagi setiap kegiatan manajemen hubungan masyarakat, tanpa perencanaan maka kegiatan atau perencanaan akan mengalami kendala dan bahkan kegagalan. Perencanaan adalah estimasi kegiatan yang ditentukan sebelumnya untuk dilaksanakan dalam rangka mencapai tujuan madarasah tersebut.

\footnotetext{
28 Muhammad Nur Hakim, 'Mengembangkan Lembaga Pendidikan ( Studi Kasus Di SMK Negeri 1 Dlanggu Mojokerto )', Jurnal Manajemen Pendidikan Islam, 4.1 (2019), 125.

29 abdul rahmat, Manajemen Humas Sekolah, Manajemen Humas Sekolah, Cetakan I (Yogyakarta: Media Akademi, 2016).

30 Mifrohatul Musyarrofah, 'Peran Humas Dalam Pengembangan Pendidikan Tinggi', Jurnal Idaarah, 2.1 (2018), 19.
} 


\section{0 | Subairi}

\section{Actuating (Pengaktifan),}

Pengaktifan merupakan tindakan menjalankan dan mengupayakan agar setiap program dilembaga madrasah dilaksanakan sesuai dengan rencana yang telah disepakati. actuating yang dilakukan ialah untuk mengaktifkan seluruh pelaksana madrasah melaksanakan tugas-tugas dengan antusias dan kemauan yang baik. ${ }^{31}$

\section{Controlling (Pengendalian).}

Controlling merupakan upaya perbaikan dan pengawasan salah satu kegiatan untuk memahami di lembaga madarasah. Pengawasan umum dengan dukungan pengontrolan, membina dan pelurusan sebagai upaya perbaikan kualitas pendidikan secara sistimatis. Pengawasan atau mengendalikan merupakan kontrol atas jalannya pelaksanaan program. Tanpa adanya kontrol atas program, kesinambungan antar tahap tidak dapat berjalan dengan baik.

4. Evaluating (Pengevaluasian)

Merupakan penilaian terhadap hasil kinerja program, perlu diperbaiki atau diselesaikan dengan modifikasi tertentu. Pada tahapan evaluasi, kinerja dalam hubungan masyarakat sangat dibutuhkan. Ada dua kriteria yang bisa dijalankan, yakni sejauhmana tujuan Lembaga madrasah terjalankan dan tercapai. Sejauh ini, dua kriteria Hubungan masyarakat dalam Lembaga madrasah dapat dinilai dari yang telah dikerjakannya yaitu:

a. pertama efektivitasnya, yaitu sejauh mana tujuan telah tercapai, misalnya apakah masyarakat benar-benar merasa terlibat dalam masalah yang dihadapi sekolah, apakah mereka ingin memberikan masukan untuk peningkatan sekolah dan sebagainya.

b. Kedua efisiennya, yaitu sejauh mana potensi sumber daya yang ada telah digunakan dengan baik untuk kepentingan kegiatan masyarakat.

Proses penilaian atau evaluasi dapat dilaksanakan pada saar kegiatan dijalankan atau pada saat kegiatan selesai. tujuannya ialah untuk memantau sejauhmana tingkat keberhasilan dan apa kendalanya. Dalam perspektif Islam disebut Muhasabah yakni menilai apa yang dikerjakan selama ini apa sudah memberikan manfaat atau belum bernilai sama sekali.

5. Pemodifikasian (pembaharuan) merupakan kegiatan pembaharuan atau revisi program berdasarkan hasil evaluasi.

Dalam kegiatan manajemen, terdapat unsur komunikasi. Hubungan dengan masyarakat sebagai kegiatan menejemen operatif merupakan kegiatan yang memikul beban tugas mewujudkan sebahagian kegiatan komunikasi keluar. Hubungan dengan masyarakat dilakukan dengan publisitas tentang kegiatan organisasi kerja yang patut diketahui oleh pihak luar secara luas. Kegiatan dilakukan dengan menyebar luaskan informasi dan memberikan penerangan untuk menciptakan pemahaman yang sebaikbaiknya dengan kalangan masyarakat luas mengenai tugas dan fungsi yang diemban oleh sekolah, termasuk kegiatan-kegiatan yang sedang, sudah dan akan dikerjakan berdasarkan volume dan beban kerjanya. Pola hubungan

31 Murni, 'Konsep Manajemen Humas Pada Lembaga Pendidikan', Jurnal Manajemen Pendidikan Islamjemen, 1.1 (2003), 26-45. 
yang harmonis anatara sekolah dan masyarakat sebagai hasil kerja sama akan menciptakan hal-hal berikut:

a. Adanya saling pengertian antara madrasah dengan pihak masyarakat,

b. Adanya kegiatan saling membantu, karena mengetahui manfaat, arti dan pentingnya peran masing-masing,

c. Adanya kerja sama dengan erat masing-masing pihak dan merasa ikut bertanggung jawab atau suksesnya usaha pihak orang lain.

Situasi ini merupakan manifestasi dari dukungan masyarakat terhadap efesiensi dan efektifitas pelaksana kerjasama yang diberikan secara sadar dan suka rela. Hubungan seperti itu timbul sebagai hasil kerja hubungan dengan masyarakat yang telah memberikan informasi sehingga pihaknya memahami pentingnya eksistensi organisasi madrasah tersebut bagi masyarakat. Ada beberapa beban kerja hubungan masyarakat dalam menciptakan madrasah unggul diantaranya: ${ }^{32}$

a. Memberikan informasi dan menyampaikan ide dan gagasan kepada masyarakat yang membutuhkannya.

b. Membantu pimpinan dengan tugas-tugasnya tidak dapat langsung memberikan informasi kepada masyarakat yang memerlukannya.

c. Membantu para pemimpin dalam menyiapkan bahan-bahan yang berkaitan dengan masalah dan informasi yang akan diberikan kepada orang-orang yang menarik pada waktu tertentu

d. Membantu para pemimpin untuk mengembangkan rencana dan menindaklanjuti kegiatan yang berkaitan dengan pelayanan kepada masyarakat, sebagai konsekuensi dari komunikasi timbal balik dengan orang luar untuk menumbuhkan harapan menyempurnakan kegiatan yang dilakukan oleh lembaga madrasah.

Untuk melaksanakan pola kerja tersebut harus dilakukan dengan berdasarkan pada konsep berikut :

a. Objektif dan serasi. Semua informasi atau pemberitaan yang disampaikan kepada masyarakat harus merupakan suatu ritual dari sekolah yang bersangkutan.

b. Organisasi yang tertib dan disiplin. Hubungan sekolah dengan masyarakat hanya akan berfungsi bilamana tugas-tugas pokok dengan organisasi sekolah berjalan secara lancer dan efektif serta memiliki hubungan kerja kedalam dan luar yang efektif pula.

c. Hubungan harus bersifat mendorong timbulnya keinginan untuk ikut berpartisipasi dan ikut memberikan dukungan secara wajar dari masyarakat.

d. Kontinuitas informasi. Hubungan masyarakat harus berusaha agar masyarakat memperoleh informasi secara kontinyu sesuai dengan kebutuhan..

e. Memperhatikan opini masyarakat. Respon yang timbul dikalangan masyarakat sebagai efek back dari informasi yang disampaikan harus mendapat perhatian yang sebenarnya dan sepenuhnya.

32 Sobry Sutikno, 'Manajemen Pendidikan, Langkah Praktis Mewujudkan Lembaga Pendidikan Yang Unggul (Tinjauan Umum Dan Islami)’ (Lombok: Holistica, 2012), p. 94. 


\section{2 | Subairi}

Inilah beberapa asas yang harus diperhatikan para pengelola madrasah dalam menjalin hubungan masyarakat untuk mewujudkan sekolah unggul. Diharapkan dengan pola kerja ini akan menciptakan pola kerja paartisipasi masyarakat semakin tinggi untuk ikut andil dalam membangun dan memajukan program-program pendidikan sekolah. Hubungan kerja sama antara madrasah dan masyarakat tak lepas dari dukungan atau dorongan orang tua yang terlibat secara aktif kedalam proses pendidikan dan pengajaran di sekolah melalui kerja sama dengan para guru dalam perencanaan program pendidikan baik secara individual maupun kolektif. Jalinan komunikasi yang efektif antara sekolah dan masyarakat dimungkinkan terjadi karena orang tua dan masyarakat secara dekat ikut berpartisipasi dengan guru dan memonitor perkembangan anak didik ke arah tercapainya nilai-nilai pendidikan, sosial, dan kepribadian baik dalam jangka pendek maupun jangka panjang.

Partisipasi yang efektif hubungan masyarakat dan madrasah sangat diperlukan untuk mencapai keberhasilan suatu lembaga pendidikan. Pertumbuhan dan perkembangan kognitif anak didik di madrasah sangat ditentukan oleh hal-hal berikut:

1. Adanya pengaruh sangat kuat dari dorongan keluarga dan masyarakat terhadap madrasah.

2. Adanya sikap positif dari anak didik terhadap keluarga dan rumah tangga.

3. Adanya peranan orang tua sebagai pengembang yang menjauhkan sikap negatif terhadap eksistensi madrasah dan pendidikan, serta kepedulian dan perasaan tertarik terhadap kurikulum madrasah dan guru.

4. Peranan dan tokoh Masyarakat dalam menciptakan hubungan masyarakat (humas) dengan madrasah

Pada prinsipnya tokoh masyarakat memainkan peranan yang sangat besar dalam menciptakan hubungan sekolah dengan masyarakat. Oleh karena itu, sekolah harus menjalin kerja sama yang erat dengan tokoh masyarakat termasuk dengan pemimpin formal masyarakat dalam rangka membina pendidikan di sekolah. Walaupun kerja sama itu tidak begitu mudah diwujudkan dikarenakan banyak hal lain yang mesti diperhatikan. Untuk merealisasikan jalinan kerja sama ini lembaga madarasah membentuk badan badan yang berfungsi memajukan dan mengaktifkan tokoh-tokoh masyarakat untuk berpartisipasi dalam usaha memajukan madarsah. Strategi yang dilakukan adalah dengan menarik perhatian masyarakat malalui peningkatan proses pendidikan dan pembinaan moralitas dan perilaku anak didik yang dilakukan oleh guru. Caranya adalah guru harus bekerja dengan baik dan memberi contoh teladan terhadap anak didik dan menanamkan nilai nilai agama, moralitas serta ilmu pengetahuan secara sempurna dan efektif.

Modal kerja dan cara kerja seperti itu akan dapat menciptakan anak didik atau lulusan seperti yang diharapkan. Prestasi kerja sekolah ini akan lebih menarik perhatian masyarakat. Perhatian masyarakat ini akan menjadi modal awal bagi peningkatan dukungan kerjasama yang erat antara 
masyarakat dan sekolah. Demikian juga perlakuan guru terhadap anak didik dalam mengajar, merupakan hal yang paling utama dalam mendukung dan menentukan sifat hubungan sekolah dengan masyarakat. Perlakuan guru yang berpusat kepada kemajuan kelas merupakan sumber penghargaan dan kepercayaan masyarakat terhadap sekolah. Strategi ini sesuai dengan realitas kehidupan yang terjadi dalam lingkungan masyarakat, karena masyarakat berusaha memasukkan anak-anaknya ke sekolah-sekolah yang bermutu (favorite). Karena sekolah yang sudah maju secara operasional dan punya citra yang baik dimata masyarakat, dan tidak sukar mengadakan hubungan akrab dengan masyarakat.

Di samping memanfaatkan guru dalam usaha meningkatkan hubungan sekolah dengan masyarakat, manajer sekolah (kepala sekolah) diharapkan pula dapat membangkitkan semangat kerja badan penghubung lembaga pendidikan dengan masyarakat seperti komite sekolah. Dengan pendekatan yang baik komite sekolah berusaha agar badan tersebut secara aktif ikut berpartisipasi dalam kegiatan sekolah. Misalnya dengan mengirimkan informasi lembaga pendidikan secara rutin, mengemukakan problemproblem yang dihadapi, menyusun kirukulum dan sebagainya. Disamping itu, perlu dibentuk satu kelompok warga masyarakat lainnya yang diharapkan dapat membantu sekolah meningkatkan hubungannya dengan masyarakat. Kelompok itu adalah alumni, khusus untuk perguruan tinggi yang merupakan satu kelompok tersendiri bersama-sama dengan kelompok lain ia diharapkan bekerja sama untuk membantu lembaga sekolah dalam menggalang hubungan kerja sama dengan masyarakat. Bantuan ini akan lebih mudah direalisasikan bila dilakukan melalui kerja sama (network) secara menyeluruh.

\section{Kesimpulan}

Dari uraian-uraian diatas, dapat disimpulkan bahwa antara madrasah dan masyarakat memiliki hubungan yang saling membutuhkan. Karena madrasah dan masyarakat merupakan dua lingkungan hidup yang tidak dapat dipisahkan, madrasah sebagai tempat belajar dan masyarakat sebagai tempat mengaplikasikan dan memetik hasil belajar. Manajemen humas merupakan bentuk wadah dalam bentuk komunikasi timbal balik yang dilakukan dengan dua arah antara organisasi dengan masyarakat dengan tujuan untuk mewujudkan fungsi dan tujuan manajemen melalui peningkatan kerja sama, serta memperhatikan kepentingan bersama. Manajemen hubungan masyarakat adalah suatu komunikasi (penyampaian informasi) yang dilakukan melalui tahap penelitian, perencanaan, pelaksanaan, dan pengevaluasian oleh lembaga atau organisasi terhadap masyarakat. fungsi humas diantaranya mengelola opini publik guna menumbuhkan partisipasi dan keterlibatan dari publik dalam rangka menciptakan opini publik yang baik, di mana humas dalam mengelola opini publik dan mensosialisasikan informasi kebijakan lembaga madrasah bekerja sama dengan media massa sehingga kegiatan di dalam maupun di luar madrasah dapat dipublikasikan dan masyarakat mengetahuinya. 


\section{4 | Subairi}

Di samping itu, Lembaga madrasah tidak hanya mementingkan pendidikan intelektual saja, tetapi pembentukan dan pengembangan pribadi anak didik juga merupakan tanggung jawab nya. Lembaga madrasah merupakan lembaga formal yang berfungsi sebagai mitra kerja keluarga dan masyarakat dalam melaksanakan tugas untuk membentuk warga masyarakat sebagaimana yang diinginkan. Hubungan masyarakat dan madrasah dibidang pendidikan harus diartikan sebagai rangkaian kegiatan organisasi atau mitra kerja dalam rangka mensukseskan proses pendidikan dan pengajaran sehingga tepat sasaran, dan sesuai dengan kebutuhan masyarakat. Jika di masyarakat berkembang opini yang baik maka secara otomatis citra yang baik akan terbentuk di masyarakat dan dalam jangka waktu yang lama akan terbentuk reputasi madrasah yang positif di mata masyarakat jika pihak humas madrasah mampu mempertahankan citra madrasah yang positif dan dapat mengolah isu-isu yang berkembang di masyarakat.

\section{Daftar Pustaka}

Abdul Rahmat, Manajemen Humas Sekolah, Manajemen Humas Sekolah, Cetakan I (Yogyakarta: Media Akademi, 2016)

Abdullah, Ma'ruf, Manajemen dan Evaluasi Kinerja Karyawan, ed. by Budi Rahmat Hakim (Yogyakarta: Aswaja Pressindo, 2014)

Afkarina, Nur Izza, 'Strategi Komunikasi Humas dalam Membentuk Public Opinion Lembaga Pendidikan', Jurnal Idaarah, 2 (2018), 61

Asrul Anam, 'Strategi Hubungan Masyarakat dalam Upaya Meningkatkan Mutu Pendidikan di Mts Darut Taqwa', Jurnal Al-Murabbi, 1 (2016), 176

Baharun, Hasan, 'Manajemen Kinerja dalam Meningkatkan Competitive Advantage Pada Lembaga Pendidikan Islam', Jurnal Ilmu Tarbiyah “At Tajdid, 5 (2016), 244

_- 'Manajemen Kinerja dalam Meningkatkan Competitive Advantage Pada Lembaga Pendidikan Islam', At-Tajdid: Jurnal Ilmu Tarbiyah, 5 (2016), 243-62

Elfridawati Mai Dhuhani, 'Manajemen Humas dalam Meningkatkan Mutu Madrasah Studi Kasus Di Madrasah Ibtidiyah Terpadu (Mit) As-Salam Ambon', Jurnal Al- i l t i z a M, 1 (2016), 40

Hakim, Muhammad Nur, 'Mengembangkan Lembaga Pendidikan ( Studi Kasus di SMK Negeri 1 Dlanggu Mojokerto )', Jurnal Manajemen Pendidikan Islam, 4 (2019), 125

Hasan, Mohammad, 'Manajemen Public Relations dalam Membangun Citra dan Kontestasi Perguruan Tinggi Keagamaan Islam Swasta (Studi Pada Sekolah Tinggi Agama Islam Syaikhona Moh. Kholil Bangkalan)', Nuansa, 14 (2017), 35

Idrangingrum, Ersin, 'Peran Kepala Sekolah dan Partisipasi dari Masyarakat dalam Implementasi Manajemen Berbasis Sekolah untuk Mewujudkan Kualitas Pendidikan Madrasah Tsanawiyah Negeri Kota Madiun', Jurnal Studi Sosial, 3 (2018), 11-21

Ira Nur Harini, 'Manajemen Hubungan Masyarakat dalam Upaya Peningkatan Pencitraan Sekolah', Jurnal Inspirasi Manajemen Pendidikan, Vol. 4 No. 4, April 2014, Hlm. 8-20, 4 (2014), 8-20

Kriyanto, 'Teknik Praktis Riset Komunikasi: Disertai Contoh Praktis Riset Media, 
Public Relations, Advertising 21' (Yogyakarta: Media Akademi, 2006), p. 21

Luqman, Yanuar, 'Peran dan Posisi Hubungan Masyarakat Sebagai Fungsi Manajemen Perguruan Tinggi Negeri Di Semarang', Interaksi: Jurnal Ilmu Komunikasi, 2 (2013) <https://ejournal.undip.ac.id/index.php/interaksi/article/view/5397/4836>

Maskur, M., 'Eksistensi dan Esensi Pendidikan Madrasah Di Indonesia', Jurnal Pendidikan Dan Pembelajaran Dasar Volume, 4 (2017), 101-19

Mubarok, Dian Marhaeni K, 'Konstruksi Prinsip Kinerja Public Relations dalam Pandangan Syariat Islam', Jurnal Messenger, VIII (2016), 20-34

Mukhtar, Jazuli, and Ichwan Nugroho, 'Pondok Pesantren ( Studi Kasus Di Pondok Pesantren As ' Adiyah Belawa Baru, Masamba , Sulawesi Selatan )', Al-Tanzim, 03 (2019), 82-101

Mulyono, 'Teknik Manajemen Humas dalam Pengembangan Lembaga Pendidikan Islam', Jurnal Ulumuna, XV (2011), 168

Murni, 'Konsep Manajemen Humas pada Lembaga Pendidikan', Jurnal Manajemen Pendidikan Islamjemen, 1 (2003), 26-45

Musyarrofah, Mifrohatul, 'Peran Humas dalam Pengembangan Pendidikan Tinggi', Jurnal Idaarah, 2 (2018), 19

Nurul, 'Strategi Manajemen Humas dalam Menyampaikan Program Unggulan Madrasah', Al Tanzim, 2 (2018), 46

Pandit Isbianti, 'Peran Humas Sebagai Upaya Menjalin Kerja Sama', Jurnal Manajemen Pendidikan, 01 (2009), 41-49

Rahutomo, Adi Nugroho, 'Strategi Humas dalam Mempublikasikan Informasi Pelayanan Publik Pada Pt Pln (Persero) Rayon di Samarinda Ilir', EJournal Ilmu Komunikasi, 1 (2013), 324-40

Rosita, Rosi, 'Usaha Kepala Sekolah dalam Meningkatkan Mutu Pendidikan Islam (Studi Kasus Di MTS AL-INAYAH Bandung)', Jurnal Tarbawy, 3 (2016), 75-89

Sugiono, 'Strategic Planning: Shaping or Emerging From Organisations', AlTanzim : Jurnal Manajemen Pendidikan Islam, 2 (2018), 177-84

Sutikno, Sobry, 'Manajemen Pendidikan, Langkah Praktis Mewujudkan Lembaga Pendidikan yang Unggul (Tinjauan Umum dan Islami)' (Lombok: Holistica, 2012), p. 94

Syamsuddin, 'Penerapan Fungsi-Fungsi Manajemen dalam Meningkatkan Mutu Pendidikan', Jurnal Idaarah, I (2017), 3-4

Trimanah, Diah Wulandari, 'Prinsip Public Relations dalam Ajaran Islam Menurut Persepsi Anggota Perhumas Jawa Tengah', Asi, Vol 11 (1), Juni 2018, 11 (2018), 66-74

Vitri Yuniarti, 'Aplikasi Manajemen Humas dalam Meningkatkan Partisipasi Masyarakat di MAN Malang 1', Jurnal Manajemen Pendidikan, 1 (2017), 5 
116 | Subairi

HALAMAN INI SENGAJA DIKOSONGKAN 